\title{
Assessment of Missouri River floodplain invertebrates during historic inundation: implications for river restoration
}

\author{
N.J.C. Gosch ${ }^{(1), \star}$, M.L. Miller ${ }^{(1)}$, A.R. Dzialowski( ${ }^{(2)}$, D.M. Morris ${ }^{(1)}$, \\ T.R. Gemeinhardt ${ }^{(1)}$, J.L. Bonneau ${ }^{(3)}$
}

Received July 25, 2013

Revised October 24, 2013

Accepted November 7, 2013

Key-words:
floodplain,
river restoration,
inundation,
prey base

\section{ABSTRACT}

Floodplain connectivity is important to aquatic organisms in large rivers. Anthropogenic alterations regulating the Missouri River have limited connectivity and negatively affected native fauna. Determining the biological response to rare inundation events may be important when considering potential restoration options on a regulated river; thus, we assessed benthic invertebrate and zooplankton communities at three floodplain sites during a historic Missouri River high-water event. Chironomid larvae dominated during most sampling trips and densities were often highest during initial sampling trips with lower densities as high water persisted. Similar trends were evident for rotifer, cladoceran, and copepod densities. Nonmetric multidimensional scaling also showed relatively high dissimilarity of densities between early and late sampling trips for benthic invertebrate and zooplankton communities. As such, short-term inundation may be more beneficial to Missouri River benthic invertebrate (mainly chironomid larvae) and zooplankton production than more prolonged inundation lasting a month or more. Furthermore, restoration projects may be designed at elevations allowing more short-term inundation, which would likely benefit native fishes with additional spawning, nursery, and foraging habitat. Levee setbacks may be an effective restoration option for increasing the amount of habitat available for short-term inundation while potentially providing socioeconomic, flood-risk reduction benefits by enhancing flow conveyance.

\section{RÉSUMÉ}

Évaluation des invertébrés de la plaine d'inondation de la rivière Missouri au cours d'une inondation historique : implications pour la restauration de la rivière

Mots-clés : La connectivité de la plaine d'inondation est importante pour les organismes aquaplaine inondable, tiques dans les grandes rivières. Les modifications anthropogéniques de régularestauration de rivière, inondation, source de proies tion de la rivière Missouri ont limité la connectivité et affecté négativement la faune indigène. Déterminer la réponse biologique à des événements d'inondation rares peut être important lors de l'examen des options de restauration possibles sur une rivière régulée; nous avons étudié les communautés d'invertébrés benthiques et de zooplancton sur trois sites d'une plaine d'inondation de la rivière Missouri au

(1) Environmental Resources Section, U.S. Army Corps of Engineers, Kansas City, MO 64106, USA

(2) Oklahoma State University, Department of Zoology, Stillwater, OK 74074, USA

(3) Threatened and Endangered Species Section, U.S. Army Corps of Engineers, Yankton, SD, USA

^ Corresponding author: Nathan.J.Gosch@usace.army.mil 
cours d'un événement historique d'inondation. Les larves de chironomes sont dominantes pendant la plupart des campagnes d'échantillonnage; les densités étaient souvent plus élevées au cours des campagnes d'échantillonnage initiales et plus faibles quand la submersion persiste. Des tendances similaires sont trouvées pour les densités de rotifères, cladocères, et copépodes. L'analyse multidimensionnelle non métrique a également montré une dissemblance relativement élevée des densités entre campagnes d'échantillonnage précoces et tardives pour les communautés d'invertébrés benthiques et de zooplancton. En tant que telle, l'inondation à court terme peut être plus bénéfique à la production d'invertébrés benthiques (principalement les larves de chironomes) et de zooplancton de la rivière Missouri que les inondations de plus longue durée, d'un mois ou plus. En outre, les projets de restauration peuvent être conçus à des altitudes permettant des inondations de plus courte durée, qui seraient susceptibles de bénéficier aux poissons indigènes avec un habitat supplémentaire de fraie, de nurserie et d'alimentation. La rupture de digue peut être une option de restauration efficace pour augmenter la quantité d'habitat disponible lors d'inondations de courte durée, tout en fournissant potentiellement des bénéfices socio-économiques de réduction des risques d'inondation en améliorant les écoulements.

\section{INTRODUCTION}

Floodplains are one of the most productive ecosystems available to aquatic organisms (Opperman et al., 2010). Primary productivity is often greater in floodplains than other aquatic or terrestrial environments; however, floodplains are also one of the most threatened ecosystems in the world (Tockner and Stanford, 2002) due largely to river regulation with dams, levees, revetments, channelization, etc. River regulation often changes the flow regime and, subsequently, floodplain connectivity by affecting the frequency, duration, and extent of floodplain inundation (Boulton and Lloyd, 1992).

The Missouri River is a prime example of a regulated river ecosystem because of dramatic alterations during the 20th century for the purposes of bank stabilization, flood control, hydropower generation, water supply, and commercial navigation. The U.S. Army Corps of Engineers (USACE) was directed to implement projects to achieve these purposes, which included the construction of the largest reservoir system in North America, resulting in a $90 \%$ reduction in floodplain habitat due to the aforementioned anthropogenic impacts (Schmulbach et al., 1992; Hesse and Mestl, 1993; Galat et al., 1998; National Research Council [NRC], 2011). These projects were successful in protecting and benefitting many human interests but the negative effects of river regulation were also evident as habitat diversity and native fish species declined (Hesse et al., 1989; Hesse and Sheets, 1993; U.S. Fish and Wildlife Service [USFWS], 2000; NRC, 2011).

As a result, the Water Resources Development Act (WRDA) of 1986 authorized the Missouri River Fish and Wildlife Mitigation Program (referred to as Mitigation Program hereafter) allowing the USACE to take measures to reduce the negative effects of river regulation and habitat loss (NRC, 2011). This authorization included the restoration of 19465 ha of land adjacent to the Missouri River between Sioux City, lowa and St. Louis, Missouri for fish and wildlife habitat (USACE, 2010), with an additional 48016 ha of land authorized by the WRDA of 1999. Native grasslands, wetlands, and bottomland forests have been restored, while increased floodplain connectivity was achieved by constructing backwaters and side channels, and levees were set back farther from the river channel.

Shortly after the WRDA of 1999, the USFWS issued a Biological Opinion in 2000 and an amendment in 2003 (collectively referred to as BIOP) recommending a large scale habitat restoration project to create shallow water habitat $\left(\mathrm{SWH},<1.5 \mathrm{~m}\right.$ deep and $<0.61 \mathrm{~m} \cdot \mathrm{s}^{-1}$ water velocity) to benefit the endangered pallid sturgeon Scaphirhynchus albus and other native species (USFWS, 2000, 2003). Types of SWH include side channel chutes, backwaters, depositional sandbars disconnected from the shoreline and low-lying depositional 
areas near the shoreline (USFWS, 2009). The BIOP called for the creation of up to 7924 ha (5.0-7.6 ha per km) of SWH on the Missouri River below Sioux City, lowa. The USACE continues to work towards meeting the requirements of the Mitigation Program and the BIOP. Unfortunately, large scale habitat restoration projects, such as the Mitigation Program and SWH restoration, are often difficult to implement because of the potential conflicts with human interests; as a result, careful evaluation of the potential options for restoration is paramount because measures that jeopardize human interests are extremely controversial and typically unsupported (Golet et al., 2006). Furthermore, understanding the biological and physical responses of restoration measures is also important to evaluating and choosing appropriate restoration techniques (Konrad et al., 2008). Unfortunately, limited information makes accurately predicting these responses difficult in large rivers like the Missouri. Relatively small restoration projects have been implemented in several European rivers and no river restoration projects of similar scale to current Missouri River efforts have been attempted in the U.S. (NRC, 2011). Therefore, studies with the potential to help guide large scale restoration projects, including research focused on assessing optimum conditions for aquatic biota at the local scale, are needed (Poulton and Allert, 2012).

During the summer of 2011, the lower Missouri River (Gavins Point Dam, SD downstream to St. Louis, MO) experienced a historic high-water event due to above-average snow melt and heavy rainfall, which produced the highest runoff during the 113-year record (Independent Post-Flood Review Panel, 2011; Jacobson et al., in press). As a result, complete reconnection of the floodplain (i.e., bluff to bluff inundation) occurred in many areas. This is rare on the Missouri River; for example, 1993 was the first reconnection of the original Missouri River floodplain in more than 20 years (Galat et al., 2004). Floodplain connectivity may be particularly important in large river systems where lateral connections are responsible for most of the aquatic biomass production, whereas small to medium-sized streams are more dependent on longitudinal connections (Junk et al., 1989). Therefore, the purpose of this study was to assess prey base response (benthic invertebrate and zooplankton communities) to prolonged floodplain inundation at three lower Missouri River floodplain sites. This effort may help guide future mitigation and habitat restoration projects designed to benefit native fishes through some mode of increased floodplain connectivity.

\section{MATERIALS AND METHODS}

\section{> STUDY AREA}

Three floodplain sites were selected for sampling (Figure 1) based on a number of factors including accessibility, safety, land ownership, land use, and degree of floodplain connectivity. All three sites are USACE mitigation sites. The farthest upstream site was Dalbey Bottoms (river kilometer [rkm 673]) located in Atchison County, Kansas. Vegetation was dominated by agricultural crops at Dalbey Bottoms and, prior to 2011, inundation was rare because of levees (USACE, 2010). The next site downstream was Baltimore Bottoms (rkm 480) located in Lafayette County, Missouri. This site is part of the USFWS Big Muddy National Fish and Wildlife Refuge and has been managed since 2002 to allow natural recovery of the land to preagricultural conditions (USACE, 2006). During this study, most of the site was covered with young trees and early successional vegetation; additionally, unrepaired levee breaches from high water during 2007 allow relatively frequent floodplain connectivity (C. Bitner, USACE, personal communication). The farthest downstream site was Overton Bottoms (rkm 299) located in Cooper and Moniteau counties, Missouri. This site is also part of the USFWS Big Muddy National Fish and Wildlife Refuge. Since the mid 1990's, natural vegetation was reestablished and now covers most of this site; additionally, unrepaired levee breaches from high water during 1993 allow relatively frequent floodplain connectivity (Spooner and Landgraf, 2006). 


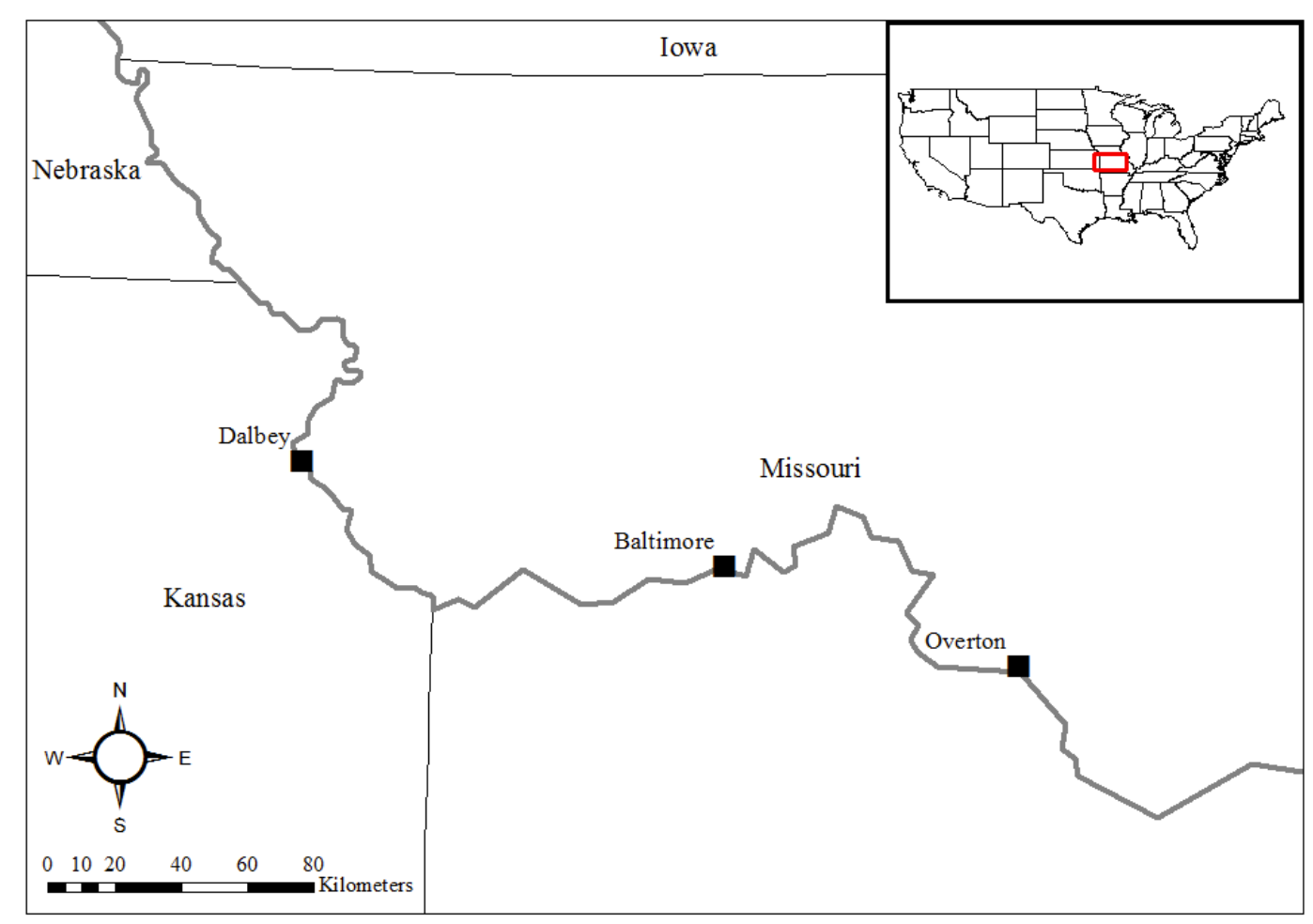

Figure 1

Map of lower Missouri River floodplain sampling sites (black squares).

\section{> SAMPLING PROCEDURES}

Each site was sampled once every two weeks as water levels allowed. We conducted six sampling trips to Dalbey and Baltimore from late June to early September. In contrast, we conducted only three sampling trips to Overton from late June to late July because quickly dropping water levels limited our ability to sample this site. Transects were established across the floodplain pool and a total of 24 sampling points were selected during each sampling trip. These sampling points were not fixed among sampling trips in order to representatively sample the entire floodplain pool as water levels fluctuated. For each sampling trip, we randomly selected 10 of the 24 sampling points for benthic invertebrate sampling; benthic invertebrates were sampled with a petite Ponar grab sampler (152 mm $\times 152 \mathrm{~mm}$ sample area). Samples were preserved in the field with ethanol and shipped to a contract laboratory. Rose bengal stain was added to the sample to facilitate sorting. Samples containing $<300$ benthic invertebrates were sorted in their entirety; more abundant samples were subsampled using grids until 300 benthic invertebrates were removed. All sorted individuals were identified to the lowest practical taxon (usually genus or species), except chironomids and oligochaetes, using Merritt et al. (2008); chironomids and oligochaetes, up to a maximum of 30 individuals per sample, were mounted on slides for identification to genus using Epler (2001) and Kathman and Brinkhurst (1999).

During each sampling trip, zooplankton samples were collected at all 24 sampling points using a $30-\mathrm{cm}$-diameter plankton net $(64-\mu \mathrm{m}$ mesh). The net was held horizontally below the water surface and a flow meter was placed in the mouth so that the total volume of river water filtered for each sample could be determined. Samples were preserved in ethanol for enumeration and identification. A sub-sample ( 1-5\% of the total sample volume depending on animal densities) was first analyzed at $100 \times$ magnification using a Sedgwick-Rafter cell to count rotifers and copepod nauplii (no additional taxonomic determinations were made for these groups). Fine-debris was then removed from the remainder of the sample by rinsing it through a $243-\mu \mathrm{m}$ mesh net. Approximately $1 \mathrm{~mL}$ of a phloxine-B dye solution $(\sim 0.1 \mathrm{~g}$ dye 
powder in $30 \mathrm{~mL}$ water) was added to aid in identification (Havel et al., 2009). While this filtering may have resulted in the loss of some smaller organisms, it was consistent across samples so that there was not a bias that would affect comparisons among sites or trips. Macrozooplankton were enumerated in a Bogorov Tray at $25 \times$ magnification in either their entirety or in 1-10 mL sub-samples until a maximum of 250 individuals had been counted. Cladocerans were identified to genus or species, and copepods were identified to sub-order using Edmondson (1959). Data were converted to densities using the horizontal, flow-adjusted tow lengths prior to analyses.

\section{$>$ DATA ANALYSIS}

Taxa richness, Pielou's evenness and the Shannon-Wiener diversity index were calculated using Primer software (version 6; Primer-E Ltd., Plymouth, England) to characterize the benthic invertebrate and zooplankton communities for each sampling trip to each site. Primer was also used to conduct a 2-way analysis of similarity (ANOSIM), using square-root transformed data and a Bray-Curtis similarity matrix, to assess the similarity of the benthic invertebrate community among sites and sampling trips. ANOSIM is similar to a standard univariate ANOVA, except that data is analyzed from a resemblance matrix and equal variance and normality assumptions are not required (Clark and Warwick, 2001). The ANOSIM procedure can produce $R$ values between -1 and 1 , but usually values range from 0 to 1 with values near 0 indicating similarity and values near 1 indicating dissimilarity. If only one factor was significant during the 2-way analysis, the non-significant factor was removed and a 1-way ANOSIM was used to strengthen the testing procedure (Clark and Gorley, 2006). Nonmetric multidimensional scaling (NMDS) was also used to corroborate the ANOSIM analysis and display the results graphically in 2-dimensional space. Samples were categorized by site (Baltimore, Dalbey or Overton) and sampling trip (1-6) and NMDS plotted values from the Bray-Curtis similarity matrix where data points located more closely together are more similar (Clark and Warwick, 2001). NMDS plots were considered sufficient to describe the data in two dimensions when stress levels were $<0.02$ (Clark and Warwick, 2001). Similar ANOSIM and NMDS analyses were conducted to assess the zooplankton communities.

The $P$-values were not the sole means of determining statistical significance when assessing the benthic invertebrate and zooplankton communities (e.g., comparisons with $P$-values $>0.05$ were not necessarily insignificant). The $R$-value is more useful to determining statistical significance than the associated $P$-value because $R$-values are an absolute measure of potential differences among groups, whereas $P$-values are a function of sample size (Clark and Gorley, 2006). Thus, the $R$-value, $P$-value, and the results of the NMDS plots were all considered when determining statistical significance. Additionally, if any significant differences existed between sites and/or sampling trips, similarity percentages procedure (SIMPER) was used to determine which taxa accounted for the dissimilarities in benthic invertebrate and/or zooplankton communities. Similar to Johnson et al. (2010), taxa contributing less than $10 \%$ of the dissimilarity were excluded.

\section{RESULTS}

We captured a total of 4113 benthic invertebrates (1653 from Baltimore, 1165 from Dalbey and 1295 from Overton) representing 10 different orders. The benthic invertebrate community changed at all three sites as high water persisted and taxa richness, evenness and diversity peaked within the first three trips (Table I). Dipterans dominated during most sampling trips at all three sites (Figure 2) and comprised at least $50 \%$ of the catch during four of six sampling trips to Baltimore, during five of six trips to Dalbey and during all three trips to Overton. Dipterans consisted almost exclusively of chironomid larvae, which comprised $98 \%$ of all dipterans captured during this study. Furthermore, Chironomus species dominated the catch of chironomid larvae during early sampling trips to Baltimore (comprised $64 \%$ and $76 \%$ of 
Table I

Benthic invertebrate species richness, Pielou's evenness, and Shannon-Wiener diversity index for each sampling trip to Baltimore, Dalbey and Overton bottoms.

\begin{tabular}{|l|c|c|c|c|}
\hline Site & Date & Richness & Evenness & Diversity \\
\hline Baltimore & $6 / 23$ & 26 & 0.52 & 1.70 \\
\cline { 2 - 5 } & $7 / 6$ & 27 & 0.44 & 1.44 \\
\cline { 2 - 5 } & $7 / 19$ & 28 & 0.86 & 2.85 \\
\cline { 2 - 5 } & $8 / 2$ & 13 & 0.86 & 2.21 \\
\cline { 2 - 5 } & $8 / 15$ & 14 & 0.86 & 2.27 \\
\cline { 2 - 5 } & $8 / 30$ & 13 & 0.74 & 1.89 \\
\hline Dalbey & $6 / 28$ & 24 & 0.34 & 1.07 \\
\cline { 2 - 5 } & $7 / 11$ & 29 & 0.82 & 2.77 \\
\cline { 2 - 5 } & $7 / 26$ & 19 & 0.85 & 2.51 \\
\cline { 2 - 5 } & $8 / 9$ & 19 & 0.72 & 2.12 \\
\cline { 2 - 5 } & $8 / 25$ & 21 & 0.76 & 2.32 \\
\cline { 2 - 5 } & $9 / 6$ & 18 & 0.69 & 1.99 \\
\hline Overton & $6 / 30$ & 21 & 0.69 & 2.11 \\
\cline { 2 - 5 } & $7 / 13$ & 31 & 0.65 & 2.24 \\
\cline { 2 - 5 } & $7 / 27$ & 36 & 0.58 & 2.09 \\
\hline
\end{tabular}

the chironomid catch during trips 1 and 2, respectively) and Dalbey (comprised $84 \%$ of the chironomid catch during trip 1). Chironomus species also comprised the largest percentage of the chironomid catch during trip $1(41 \%)$ and trip $2(49 \%)$ to Overton. The chironomid catch during late sampling trips (i.e., trips 3-6) was usually more evenly distributed among several chironomid larvae taxa (e.g., Coelotanypus, Dicrotendipes and Tanypus species) including Chironomus species. At Baltimore, oligochaetes tended to increase as dipteran chironomid larvae decreased (Figure 2) and oligochaetes comprised over $70 \%$ of the catch during the last sampling trip. The benthic invertebrate community did not differ among sites but differences existed among sampling trips (Table II); early sampling trips (e.g., trips 1-2) usually had the highest mean density, particularly for dipteran chironomid larvae (Figure 2). Similarly, the NMDS plot indicated that early sampling trips (trips 1-2) to Baltimore and Dalbey and all trips to Overton were usually more similar to each other than to late trips (i.e., trips 4-6) (Figure 3). Chironomus species were largely responsible for the differences in benthic invertebrate communities between early and late sampling trips as this was the only taxa responsible for at least $10 \%$ dissimilarity (range: 10.9 to $15.7 \%$ ) for all but one of the significant pairwise comparisons reported in Table II.

Zooplankton communities at all three floodplain sites mainly consisted of individuals from three major taxa (rotifera, cladocera, and copepoda). At Dalbey, taxa richness peaked during trip 2 and evenness and diversity peaked during trip 6; evenness and diversity was high during trip 1 (Table III). At Baltimore and Overton, taxa richness, evenness and diversity peaked within the first three trips (Table III). Rotifers were dominant during all sampling trips to each site, except for trip 6 to Dalbey (Figure 4), comprising at least 95\% of the zooplankton catch during all trips to Baltimore and Overton and during five of six trips to Dalbey. The zooplankton community did not differ among sites but differences existed among sampling trips (Table II); early sampling trips (e.g., trips 1-2) usually had the highest mean density (Figure 4); trip 6 to Dalbey also had relatively high densities. Similarly, the NMDS plot indicated that early sampling trips (trips 1-2) to Baltimore and Dalbey and all sampling trips to Overton were usually more similar to each other than to late trips (trips 4-6) (Figure 5). Rotifers accounted for the largest percentage of dissimilarity in zooplankton communities between early and late sampling trips, followed by copepod nauplii, for four of the six significant pairwise comparisons reported in Table II (Table IV). In contrast, copepod nauplii accounted for the largest percentage of dissimilarity, followed by rotifers, for the other two significant pairwise comparisons reported in Table II (Table IV). Additionally, cladoceran species also accounted for least $10 \%$ of the dissimilarity between zooplankton communities for significant comparisons involving trip 6 (Table IV). 


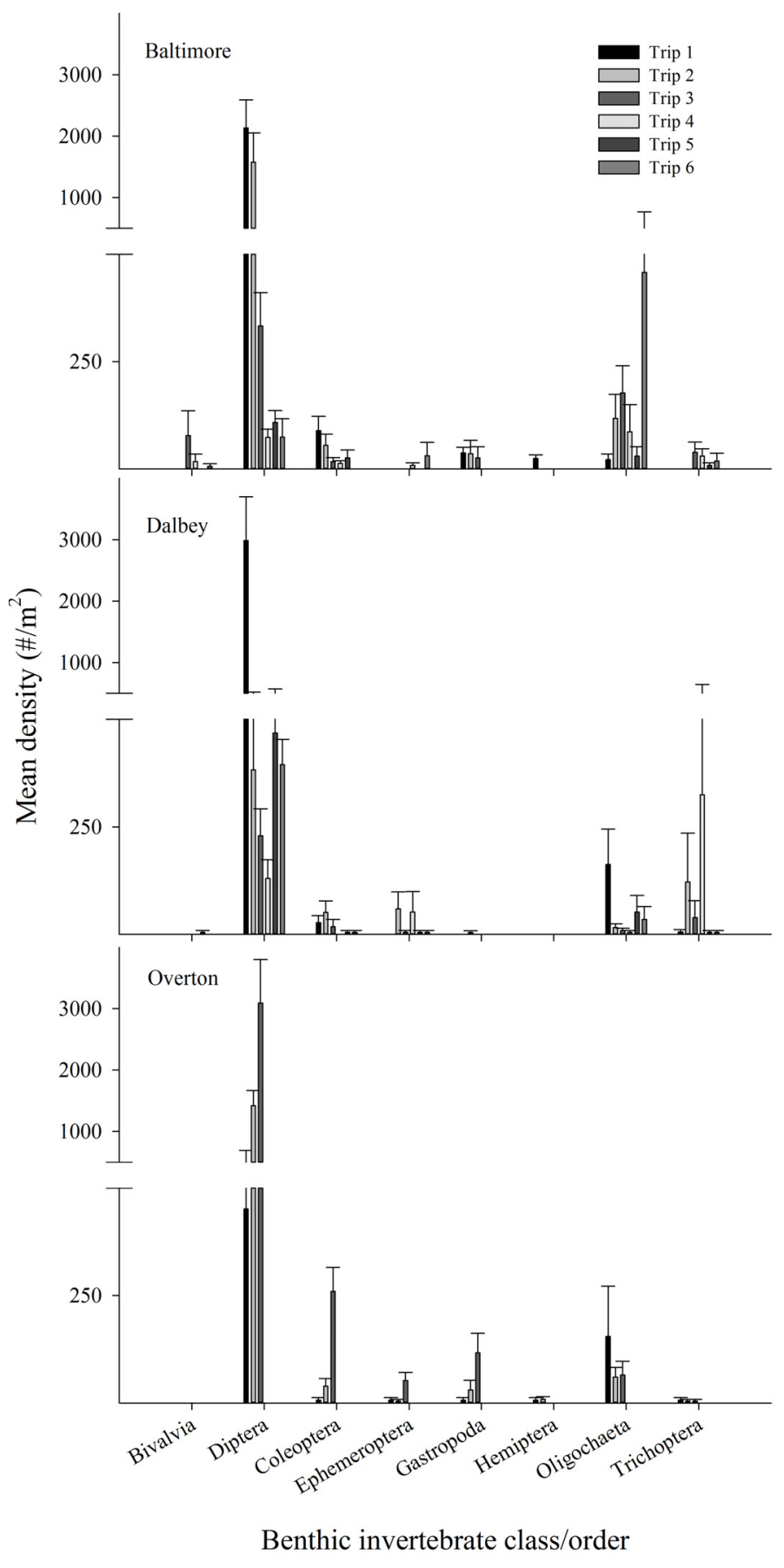

\section{Figure 2}

Mean density \pm SE of benthic invertebrates by class or order for each sampling trip to Baltimore, Dalbey and Overton. Chironomid larvae comprised $98 \%$ of all dipterans captured.

\section{DISCUSSION}

The benthic invertebrate communities at Baltimore, Dalbey and Overton were similar despite the differences in floodplain connectivity, land use and location (i.e., 180 to $370 \mathrm{rkm}$ separating these sites). This similarity is largely a function of the dominance of dipteran chironomid larvae during most of the sampling trips during this high-water event. Dominance of chironomid larvae on the floodplain is not surprising because they are well adapted to temporary aquatic habitats (Wiggins et al., 1980, Sommer et al., 2004). Similarly, chironomids comprised 


\section{Table II}

$R$ statistic and P-values for 2-way analysis of similarity (ANOSIM) for the benthic invertebrate and zooplankton communities using site (Baltimore, Dalbey and Overton) and sampling trip (1-6) as factors. Significant global models and pairwise comparisons are bolded. If only one factor was significant, then a 1-way ANOSIM with only the significant factor was used.

\begin{tabular}{|l|c|c|c|c|}
\hline & $\boldsymbol{R}$ & $\boldsymbol{P}$ & $\boldsymbol{R}$ & $\boldsymbol{P}$ \\
\hline & \multicolumn{2}{|c|}{ Benthic } & Invertebrate & \multicolumn{2}{c|}{ Zooplankton } \\
\hline Global among sites & -0.33 & 0.95 & -0.50 & 1.00 \\
\hline Global among trips & $\mathbf{0 . 6 5}$ & $\mathbf{0 . 0 4}$ & $\mathbf{0 . 3 9}$ & $\mathbf{0 . 1 8}$ \\
\hline 1-way global among trips & $\mathbf{0 . 4 1}$ & $\mathbf{0 . 0 2}$ & $\mathbf{0 . 3 9}$ & $\mathbf{0 . 0 1}$ \\
\hline $\mathbf{1}$ vs. $\mathbf{2}$ & 0.08 & 0.40 & 0.08 & 0.50 \\
\hline $\mathbf{1}$ vs. $\mathbf{3}$ & 0.15 & 0.30 & 0.29 & 0.20 \\
\hline $\mathbf{1}$ vs. $\mathbf{4}$ & $\mathbf{1 . 0 0}$ & $\mathbf{0 . 1 0}$ & $\mathbf{1 . 0 0}$ & $\mathbf{0 . 1 0}$ \\
\hline $\mathbf{1}$ vs. $\mathbf{5}$ & $\mathbf{1 . 0 0}$ & $\mathbf{0 . 1 0}$ & $\mathbf{1 . 0 0}$ & $\mathbf{0 . 1 0}$ \\
\hline $\mathbf{1}$ vs. $\mathbf{6}$ & $\mathbf{0 . 9 2}$ & $\mathbf{0 . 1 0}$ & $\mathbf{0 . 5 0}$ & $\mathbf{0 . 1 0}$ \\
\hline $\mathbf{2}$ vs. $\mathbf{3}$ & 0.00 & 0.50 & 0.19 & 0.20 \\
\hline $\mathbf{2}$ vs. $\mathbf{4}$ & $\mathbf{0 . 5 8}$ & $\mathbf{0 . 2 0}$ & $\mathbf{1 . 0 0}$ & $\mathbf{0 . 1 0}$ \\
\hline $\mathbf{2}$ vs. $\mathbf{5}$ & $\mathbf{1 . 0 0}$ & $\mathbf{0 . 1 0}$ & $\mathbf{0 . 9 2}$ & $\mathbf{0 . 1 0}$ \\
\hline $\mathbf{2}$ vs. $\mathbf{6}$ & $\mathbf{1 . 0 0}$ & $\mathbf{0 . 1 0}$ & $\mathbf{0 . 5 0}$ & $\mathbf{0 . 1 0}$ \\
\hline $\mathbf{3}$ vs. $\mathbf{4}$ & 0.17 & 0.50 & 0.17 & 0.30 \\
\hline $\mathbf{3}$ vs. $\mathbf{6}$ & 0.08 & 0.40 & 0.33 & 0.30 \\
\hline $\mathbf{3}$ vs. $\mathbf{6}$ & $\mathbf{0 . 4 2}$ & $\mathbf{0 . 1 0}$ & -0.25 & 0.90 \\
\hline $\mathbf{4}$ vs. $\mathbf{5}$ & 0.00 & 0.67 & 0.25 & 0.33 \\
\hline $\mathbf{4}$ vs. $\mathbf{6}$ & -0.25 & 1.00 & 0.25 & 0.33 \\
\hline $\mathbf{5}$ vs. $\mathbf{6}$ & 0.25 & 0.67 & 0.00 & 0.67 \\
\hline
\end{tabular}

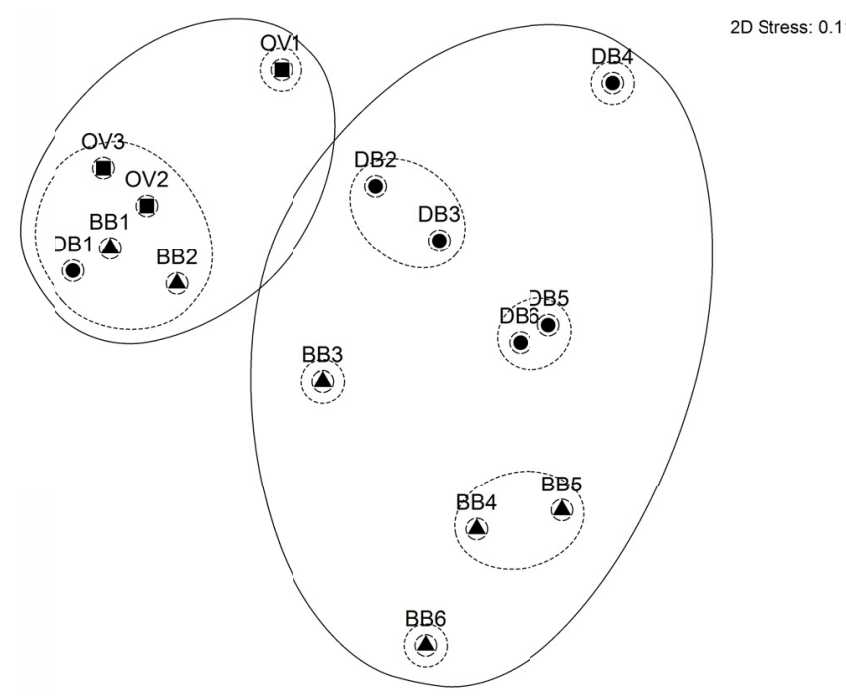

Figure 3

Nonmetric multidimensional scaling plot of the benthic invertebrate communities collected from three Missouri River floodplain sites (BB [triangle] = Baltimore, DB [circle] = Dalbey, OV [square] = Overton) during each sampling trip (1-6). Data points located more closely together are more similar and contour lines indicate the percentage of similarity among these points (solid line $=25 \%$, line with short dashes $=$ $50 \%$, and line with long dashes $=75 \%$ ).

over $90 \%$ of the catch from emergence traps in Missouri River floodplain wetlands following the high-water event of 1993 (Galat et al., 1998). During early sampling trips (trips 1-2), Chironomus larvae usually dominated the chiromonid catch at all three sites. Similarly, Poulton and Allert (2012) found that Chironomus were among the most dominant midge taxa at oxygen-poor dike pool sites on the lower Missouri River. This genus is particularly effective at colonizing new aquatic habitats by extending the emergence period during summer (Cantrell and McLachlan, 1977) and utilizing hemoglobin to temporarily store oxygen in the 


\section{Table III}

Zooplankton taxa richness, Pielou's evenness, and Shannon-Wiener diversity index for each sampling trip to Baltimore, Dalbey and Overton bottoms.

\begin{tabular}{|l|c|c|c|c|}
\hline Site & Date & Richness & Evenness & Diversity \\
\hline Baltimore & $6 / 23$ & 20 & 0.13 & 0.38 \\
\cline { 2 - 5 } & $7 / 6$ & 35 & 0.21 & 0.76 \\
\cline { 2 - 5 } & $7 / 19$ & 25 & 0.12 & 0.38 \\
\cline { 2 - 5 } & $8 / 2$ & 26 & 0.19 & 0.61 \\
\cline { 2 - 5 } & $8 / 15$ & 21 & 0.06 & 0.18 \\
\cline { 2 - 5 } & $8 / 30$ & 19 & 0.09 & 0.28 \\
\hline Dalbey & $6 / 28$ & 23 & 0.23 & 0.74 \\
\cline { 2 - 5 } & $7 / 11$ & 35 & 0.12 & 0.42 \\
\cline { 2 - 5 } & $7 / 26$ & 24 & 0.09 & 0.28 \\
\cline { 2 - 5 } & $8 / 9$ & 16 & 0.10 & 0.27 \\
\cline { 2 - 5 } & $8 / 25$ & 23 & 0.07 & 0.21 \\
\cline { 2 - 5 } & $9 / 6$ & 9 & 0.53 & 1.16 \\
\hline Overton & $6 / 30$ & 22 & 0.21 & 0.65 \\
\cline { 2 - 5 } & $7 / 13$ & 27 & 0.22 & 0.72 \\
\cline { 2 - 5 } & $7 / 27$ & 28 & 0.16 & 0.52 \\
\hline
\end{tabular}

\section{Table IV}

Percentage of dissimilarity for taxa contributing at least $10 \%$ of the dissimilarity between zooplankton communities as calculated by similarity percentages procedure (SIMPER). Results were limited to significantly different pairwise trip comparisons (reported in Table II).

\begin{tabular}{|c|c|c|}
\hline Trip comparison & Taxa & $\%$ dissimlarity \\
\hline \multirow{2}{*}{1 vs. 4} & Rotifers & 50.6 \\
\hline & Nauplii & 26.6 \\
\hline \multirow[t]{2}{*}{1 vs. 5} & Rotifers & 45.2 \\
\hline & Nauplii & 30.2 \\
\hline \multirow[t]{3}{*}{1 vs. 6} & Rotifers & 29.2 \\
\hline & Nauplii & 24.4 \\
\hline & Moina micrura & 14.0 \\
\hline \multirow[t]{2}{*}{2 vs. 4} & Rotifers & 44.8 \\
\hline & Nauplii & 39.5 \\
\hline \multirow[t]{2}{*}{2 vs. 5} & Nauplii & 46.5 \\
\hline & Rotifers & 34.7 \\
\hline \multirow[t]{4}{*}{2 vs. 6} & Nauplii & 30.2 \\
\hline & Rotifers & 20.9 \\
\hline & Moina micrura & 17.1 \\
\hline & Diaphanasoma birgei & 11.7 \\
\hline
\end{tabular}

blood (Panis et al., 1995) allowing these species to survive periods of low dissolved oxygen that often occur in newly-flooded habitats (Cantrell and McLachlan, 1977).

As high water persisted, Baltimore and Dalbey experienced declines in chironomid larvae density as Chironomus numbers declined. This decline may be a function of life history and migration from floodplain habitat as larvae transitioned to pupae and adult stages; however, other factors may also have contributed to the observed declines, such as predation pressure by fishes. It is also possible that chironomid larvae were displaced by other benthic invertebrates following an initial chironomid boom (Cantrell and McLachlan, 1977). For example, oligochaetes comprised a larger percentage of the catch at Baltimore when Chironomus abundance decreased. This shift in catch may also be explained by extended periods of low oxygen levels in floodplain sediments as high water persisted (Baldwin and Mitchell, 2000) because oligochaetes can be more tolerant than chironomids under harsh conditions (Wiederholm, 1980), including low dissolved oxygen (Mandaville, 2002). Another possible explanation for the increase in oligochaete abundance is reduced predation. Chironomids, such as Chironomus attenuates, frequently consume oligochaetes and are capable of controlling 


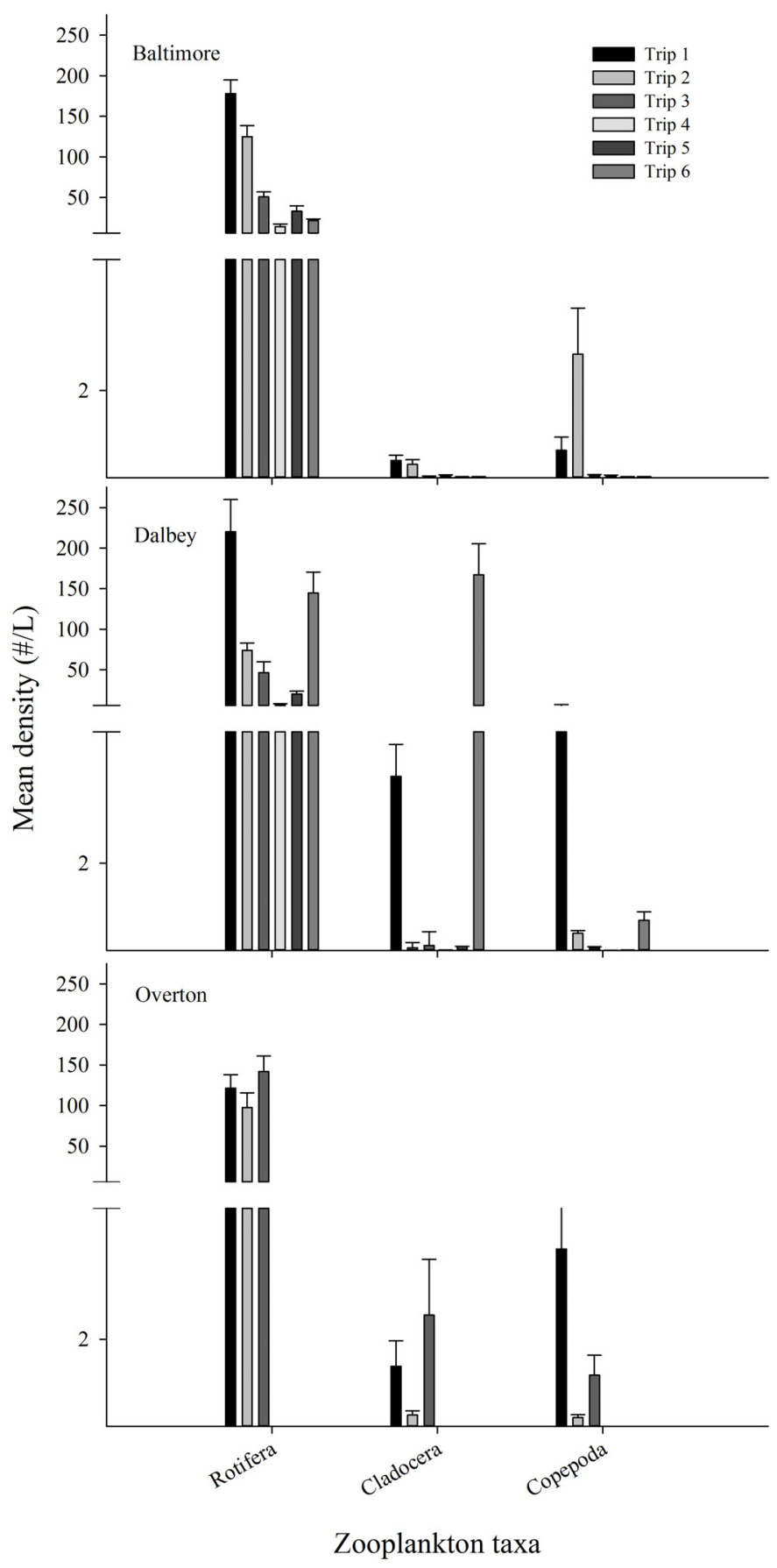

Figure 4

Mean density \pm SE of major zooplankton taxa for each sampling trip to Baltimore, Dalbey and Overton bottoms.

oligochaete abundance (Loden, 1974). When Chironomus numbers declined, oligochaetes may have experienced reduced predation pressure allowing them to reach higher densities.

At Overton, chironomid larvae were also dominant but, unlike Baltimore and Dalbey, this site did not experience an initial peak in chironomid density. In contrast, chironomid larvae catch increased as summer progressed; however, we were only able to complete three sampling trips to Overton before water levels dropped. It is unknown how the benthic invertebrate community would have responded at this site had inundation persisted. Regardless, relatively high chironomid larvae densities were observed during the three 


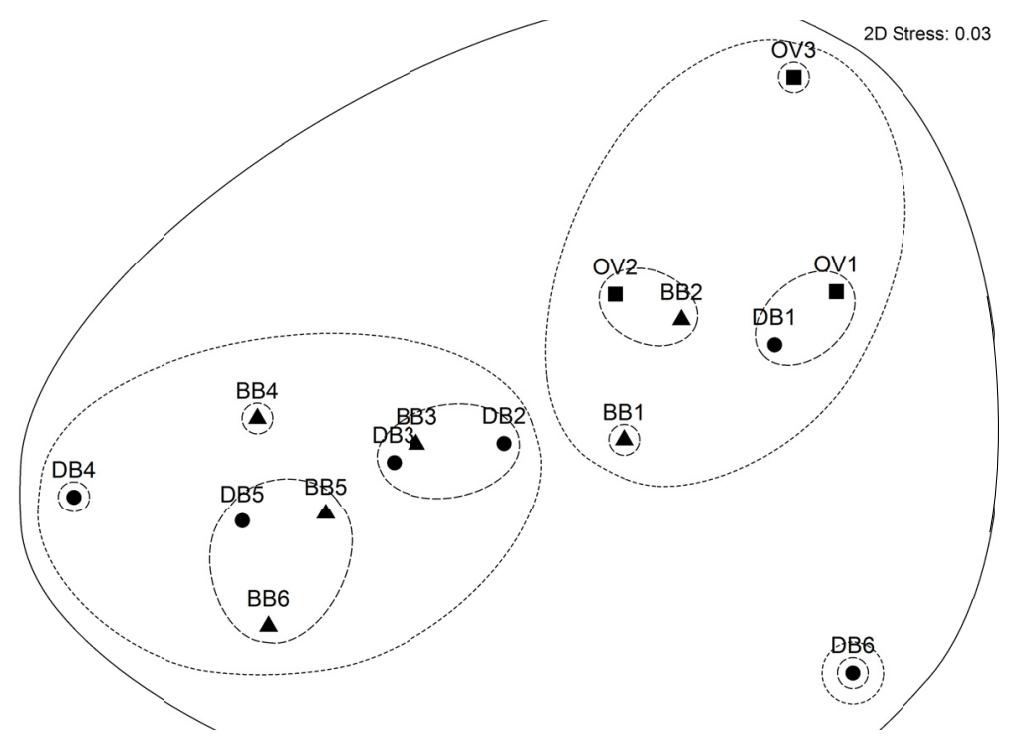

\section{Figure 5}

Nonmetric multidimensional scaling plot of the zooplankton communities collected from three Missouri River floodplain sites (BB [triangle] = Baltimore, DB [circle] = Dalbey, OV [square] = Overton) during each sampling trip (1-6). Data points located more closely together are more similar and contour lines indicate the percentage of similarity among these points (solid line $=25 \%$, line with short dashes $=50 \%$, and line with long dashes $=75 \%$ ).

sampling trips to Overton. Thus, high densities of chironomid larvae were sampled during the first month of high water at all three floodplain sites. Furthermore, these densities usually exceeded mean densities sampled from other lower Missouri River habitats including five of six depositional sites (<550 chironomids.m ${ }^{-2}$ [Poulton et al., 2003]), 18 dike pool sites ( $<630$ chironomids $\cdot \mathrm{m}^{-2}$ [Poulton and Allert, 2012]), and four constructed chute sites (434 chironomids $\mathrm{m}^{-2}$ [Sampson and Hall, 2011]). In contrast, mean density at four constructed backwater sites (1999 chironomids. $\mathrm{m}^{-2}$ [Sampson and Hall, 2011]) was relatively similar to our peak floodplain densities. Additionally, taxa richness, evenness and diversity peaked during the first month of high water at Baltimore and Dalbey. Thus, our results suggest that areas that experience short-term inundation (e.g., $<1$ month) may be more beneficial to chironomid production and benthic invertebrate richness, evenness and diversity than prolonged inundation (e.g., $\geqslant 1$ month) during high-water events on the Missouri River.

Much like our benthic invertebrates results, zooplankton communities were similar at Baltimore, Dalbey and Overton. This similarity among sites is largely a function of the frequent dominance of rotifers during our study. Rotifers have long been the most abundant zooplankton on the Missouri River (Berner, 1951) and abundance has increased since dam construction because of clearer water conditions during the post-dam era (Blevins, 2011). Interestingly, densities for all three major zooplankton taxa, including rotifers, declined as high water persisted. Similarly, Galat et al. (1998) found that cladocerans and copepods were more abundant in periodically connected Missouri River floodplain wetlands than continuously connected wetlands. The exception to declining zooplankton densities as high water persisted occurred during the last sampling trip to Dalbey when densities rebounded dramatically for rotifers and cladocerans; this coincided with lower water levels that disconnected the Dalbey floodplain from the river creating a lentic environment more conducive to zooplankton production than lotic environments (Wetzel, 2001).

At Overton, fewer sampling trips again made comparison with the other sites difficult. However, much like the chironomid larvae, rotifers were dominant during all three sampling trips to Overton but, unlike Baltimore and Dalbey, this site did not experience the initial peak in rotifer density. In contrast, relatively high rotifer densities were observed during each trip to this site. Thus, high densities of rotifers were sampled during the first month of high water at 
all three floodplain sites. Mean rotifer densities sampled during the first month of floodplain sampling often exceeded those sampled from other lower Missouri River habitats including created backwater $\left(<35\right.$ rotifers. $\left.\mathrm{L}^{-1}\right)$ and SWH chute sites $\left(<10\right.$ rotifers. $\left.\mathrm{L}^{-1}\right)$ (Dzialowski et al., 2013) and the mainstem of the Missouri River near Dalbey ( $<100$ rotifers. $L^{-1}$, USACE unpublished data); in contrast, mean densities from mainstem samples near Baltimore were as high as 290 rotifers. $\mathrm{L}^{-1}$ (USACE unpublished data) demonstrating that rotifer densities in the mainstem are capable of exceeding floodplain densities. Additionally, taxa richness, evenness and diversity peaked early at Baltimore and Dalbey (excluding trip 6 because of the lentic conditions discussed above). Similarly, Galat et al. (1998) concluded that recurrent flooding contributed to the maintenance of a diverse zooplankton community. Thus, shortterm inundation may also be more beneficial to Missouri River zooplankton (especially rotifer) production and taxa richness, evenness and diversity than prolonged inundation ( $\geqslant 1$ month).

Increased zooplankton production and taxa richness, diversity and evenness may benefit native fishes because almost all fishes rely on zooplankton during early life history (Miller et al., 1988). Similarly, chironomid production may also be important to some species, such as Scaphirhynchus sturgeon; age-0 shovelnose $S$. platorynchus and pallid sturgeon in the middle Mississippi River clearly preferred chironomids over other prey suggesting that the enhancement or creation of habitats that aid the production of benthic invertebrates, such as chironomids, is essential for successful recruitment of these young sturgeon in large rivers (Sechler et al., 2012). Clearly, many native fishes could benefit from increased prey and future restoration projects could potentially be designed to allow more frequent and short-term inundation, which may maximize chironomid larvae and zooplankton production.

Thus, more frequent, short-term inundation may generate ecosystem benefits (e.g., increased prey for native fishes), which are an important component to restoration projects. As such, levee setbacks (i.e., relocating an existing levee farther away from the river) may be an attractive option for river restoration projects because these setbacks may restore some fluvial habitat-forming processes (Konrad et al., 2008) while providing simultaneous societal benefits (e.g., flood-risk reduction). Several models from completed and proposed USACE Missouri River setback projects suggested reductions in the $1 \%$ exceedance probability flood stage (i.e., 100-year return interval) and water velocities up to $1.22 \mathrm{~m}$ and $0.82 \mathrm{~m} \cdot \mathrm{s}^{-1}$, respectively (Missouri River Recovery Program, 2013; USACE, 2012, 2013). Furthermore, modeling by Jacobson et al. (In press) suggested that USACE levee setbacks of $305 \mathrm{~m}$ coupled with river widening of $46 \mathrm{~m}$ (both realistic distances based on current efforts) reduced the $10 \%$ exceedance probability flood stage by approximately $0.39 \mathrm{~m}$ with the potential to delay the peaking of flows by several hours.

If flood-risk reduction benefits are realized, this could have important economic benefits related to reduced flood damages. For example, hydraulic modeling revealed that strategically locating levee setbacks in the middle Mississippi River would reduce expected annual flood damage by $7 \%$ and $43 \%$ in urban and agricultural reaches, respectively (Dierauer et al., 2012); additionally, the ability to buyout unprotected structures further decreased expected annual flood damage by $55 \%$ and $93 \%$ in these respective reaches. Golet et al. (2006) also concluded that levee setback in the Sacramento River, California could effectively reduce flood damages, improve ecosystem health and generate strong local support by having minimal adverse effects on the local economy. Implementing projects that benefit ecosystem health and human interests are critical to future restoration efforts and levee setbacks have the potential to support both of these objectives. Furthermore, successful implementation of restoration projects that include levee setbacks on the Missouri River could be a catalyst for future setback projects on other large rivers because understanding the ecological effects of restoration projects is critical to justifying future restoration projects (Konrad et al., 2008).

Specific to the Missouri River, the construction of side-channel chutes is a common restoration method with many chutes already constructed and additional proposed chute projects currently in the planning stages (Gosch et al., 2013). Levee setbacks may be particularly valuable to future chute restoration projects by increasing the amount of land available for chute migration and development. However, if levee setbacks are utilized, further monitoring should 
be conducted to determine benthic invertebrate and zooplankton community response. Levee setback floodplains will typically be inundated at much lower stage heights compared to the stages experienced during this study and many abiotic and biotic factors may be important in determining zooplankton and benthic invertebrate response to inundation (Boulton and Lloyd, 1992). Furthermore, recently developed metrics identifying environmental conditions required to optimize aquatic macroinvertebrate productivity and diversity could be incorporated into future monitoring efforts to better assess the success of large river restoration projects (Poulton and Allert, 2012).

\section{ACKNOWLEDGEMENTS}

We thank numerous U.S. Army Corps of Engineers staff for field assistance. George Williams, William Covington, Jason Farmer, Chance Bitner and Randall Behm provided valuable comments on an earlier draft of this manuscript. This study was funded by the U.S. Army Corps of Engineers Kansas City District. The contents of this report are not to be used for advertising, publication, or promotional purposes. Reference to trade names does not imply endorsement by the U.S. Government. All product names and trademarks cited are the property of their respective owners. The findings of this report are not to be construed as an official Department of Army position unless so designated by other authorized documents.

\section{REFERENCES}

Baldwin D.S. and Mitchell A.M., 2000. The effects of drying and re-flooding on the sediment and soil nutrient dynamics of lowland river-floodplain systems: a synthesis. Regul. Rivers Res. Manag., 16, 457-467.

Berner L.M., 1951. Limnology of the lower Missouri River. Ecology, 32, 1-12.

Blevins D.W., 2011. Water-quality requirements, tolerances, and preferences of pallid sturgeon (Scaphirhynchus albus) in the lower Missouri River. U.S. Geological Survey Scientific Investigations Report 2011-5186, $20 \mathrm{p}$.

Boulton A.J. and Lloyd L.N., 1992. Flooding frequency and invertebrate emergence from dry floodplain sediments of the River Murray, Australia. Regul. Rivers Res. Manag., 7, 137-151.

Cantrell M.A. and McLachlan A.J., 1977. Competition and chironomid distribution patterns in a newly flooded lake. Oikos, 29, 429-433.

Clarke K.R. and Warwick R.M., 2001. Change in marine communities: an approach to statistical analysis and interpretation, 2nd edn. Primer-E, Plymouth, $168 \mathrm{p}$.

Clarke K.R. and Gorley R.N., 2006. Primer version 6 user manual/tutorial. Primer-E, Plymouth, 190 p.

Dierauer J., Pinter N. and Remo J.W.F., 2012. Evaluation of levee setbacks for flood-loss reduction, Middle Mississippi River, USA. J. Hydrol., 450-451, 1-8.

Dzialowski A.R., Bonneau J.L. and Gemeinhardt T.R., 2013. Comparisons of zooplankton and phytoplankton in created shallow water habitats of the lower Missouri River: implications for native fish. Aquat. Ecol., 47, 13-24.

Edmondson W.T., 1959. Freshwater biology. John Wiley \& Sons, New York.

Galat D.L., Fredrickson L.H., Humburg D.D., Bataille K.J., Bodie J.R., Dohrenwend J., Gelwicks G.T., Havel J.E., Helmers D.L., Hooker J.B., Jones J.R., Knowlton M.F., Kubisiak J., Mazourek J., McColpin A.C., Renken R.B. and Semlitsch R.D., 1998. Flooding to restore connectivity of regulated, large-river wetlands. Bioscience, 48, 721-733.

Galat D.L., Whitledge G.W. and Gelwicks G.T., 2004. Influence of lateral connectivity on larval fish assemblage structure and habitat use in lower Missouri River floodplain water bodies. Final Report to Missouri Department of Conservation. U.S. Geological Survey, Missouri Cooperative Fish and Wildlife Research Unit, University of Missouri, Columbia. $114 \mathrm{p}$

Golet G.H., Roberts M.D., Luster R.A., Werner G., Larsen E.W., Unger R. and White G.G., 2006. Assessing societal impacts when planning restoration of large alluvial rivers: a case study of the Sacremento River Project, California. Environ. Manag., 37, 862-879. 
Gosch N.J.C., Morris D.M., Gemeinhardt T.R. and Bonneau J.L., 2013. Pre- and post-construction assessment of nutrient concentrations at shallow water habitat restoration sites on the lower Missouri River. J. Water Resour. Prot., 5, 249-258.

Havel J.E., Medley K.A., Dickerson K.D., Angradi T.R., Bolgrien D.W., Bukaveckas P.A., Jicha T.M., 2009. Effect of mainstem dams on zooplankton communities of the Missouri River (USA). Hydrobiologia, $628,121-135$

Hesse L.W. and Mestl G.E., 1993. An alternative hydrograph for the Missouri River based on the precontrol condition. North Am. J. Fish. Manag., 13, 360-366.

Hesse L.W. and Sheets W., 1993. The Missouri River hydrosystem. Fisheries, 18, 5-14.

Hesse L.W., Schmulbach J.C., Carr J.M., Keenlyne K.D., Unkenholz D.G., Robinson J.W. and Mestl G.E., 1989. Missouri River fishery resources in relation to past, present, and future stresses. Can. Spec. Publ. Fish. Aquat. Sci., 106, 352-371.

Independent Post-Flood Review Panel, 2011. Review of the regulation of the Missouri River mainstem reservoir system during the flood of 2011.

Jacobson R.B., Linder G. and Bitner C.J., In press. The role of floodplain restoration in mitigating flood risk, lower Missouri River, USA. In: Hudson P.F. and Middlekoop H. (eds.), Geomorphology and management of lowland floodplains: North American and European fluvial systems in an era of global environmental change, Springer, New York.

Johnson M.W., Powers S.P., Hightower C.L. and Kenworthy M., 2010. Age, growth, mortality, and diet composition of vermilion snapper from the north-central Gulf of Mexico. Trans. Am. Fish. Soc., 139, 1136-1149.

Junk W.J., Bayley P.B. and Sparks R.E., 1989. The flood pulse concept in river-floodplain systems. Can. Spec. Publ. Fish. Aquat. Sci., 106, 110-127.

Konrad C.P., Black R.W., Voss F. and Neale C.M.U., 2008. Integrating remotely acquired and field data to assess effects of setback levees on riparian and aquatic habitats in glacial-melt water rivers. River Res. Appl., 24, 355-372.

Loden M.S., 1974. Predation by chironomid (diptera) larvae on oligochaetes. Limnol. Oceanogr., 19, 156-159.

Mandaville S.M., 2002. Benthic macroinvertebrates in freshwaters - taxa tolerance, values, metrics, and protocols. Soil and Water Conservation Society of Metro Halifax.

Miller T.J., Crowder L.B., Rice J.A. and Marschall E.A., 1988. Larval size and recruitment mechanisms in fishes: toward a conceptual framework. Can. Spec. Publ. Fish. Aquat. Sci., 45, 1657-1670.

Missouri River Recovery Program, 2013. Recovery channel newsletter, April, 4 p.

NRC, 2011. Missouri River planning, recognizing and incorporating sediment management. The National Academies Press, Washington D.C., 152 p.

Opperman J.J., Luster R., McKenney B.A., Roberts M. and Meadows A.W., 2010. Ecologically functional floodplains: connectivity, flow regime and scale. J. Am. Water Resour. Assoc., 46, 211-226.

Panis L.I., Goddeeris B. and Verheyen R., 1995. The hemoglobin concentration of Chironomus Cf. plumosus L. (Diptera: Chironomidae) larvae from two lentic habitats. Neth. J. Aquat. Ecol., 29, 1-4.

Poulton B.C. and Allert A.L., 2012. An evaluation of the relative quality of dike pools for benthic macroinvertebrates in the lower Missouri River, USA. River Res. Appl., 28, 1658-1679.

Poulton B.C., Wildhaber M.L., Charbonneau C.S., Fairchild J.F., Mueller B.G. and Schmitt C.J., 2003. A longitudinal assessment of the aquatic macroinvertebrate community in the channelized lower Missouri River. Environ. Monit. Assess., 85, 23-53.

Sampson S.J. and Hall J.R., 2011. Habitat assessment and monitoring program : macroinvertebrate community assessment of constructed backwaters and side channels of the channelized Missouri River, 2010. Nebraska Game and Parks Commission, Lincoln, 26 p.

Sechler D.R., Phelps Q.E., Tripp S.J., Garvey J.E., Herzog D.P., Ostendorf D.E., Ridings J.W., Crites J.W. and Hrabik R.A., 2012. Habitat for age-0 shovelnose and pallid sturgeon in a large river: interactions among abiotic factors, food, and energy intake. North Am. J. Fish. Manag., 32, 24-31.

Schmulbach J.C., Hesse L.W. and Bush J.E., 1992. The Missouri River-Great Plains thread of life. In: Becker C.D. and Nietzel D.A. (eds) Water quality in North American river systems, Batelle Press, Columbus, 137-158.

Sommer T.R., Harrell W.C., Mueller-Solger A., Tom B. and Kimmerer W., 2004. Effects of flow variation on channel and floodplain biota and habitats of the Sacramento River, California, USA. Aquat. Conserv. Mar. Freshw. Ecosyst., 14, 247-261. 
Spooner J.D. and Landgraf K.F., 2006. Retrospective analysis of land cover at Overton Bottoms North, Missouri. In: Jacobson R.B. (ed.), Science to support adaptive habitat management-Overton Bottoms North Unit, Big Muddy National Fish and Wildlife Refuge, Missouri. U.S. Geological Survey, Scientific Investigations Report 2006-5086, 69-90.

Tockner K. and Stanford J.A., 2002. Riverine floodplains: present state and future trends. Environ. Conserv., 29, 308-330.

USACE, 2006. Missouri River bank stabilization and navigation fish and wildlife mitigation program, Baltimore Bottom USFWS Big Muddy Fish and Wildlife Refuge chute construction project. Project Implementation Report November 2006, 166 p.

USACE, 2010. Missouri River fish and wildlife mitigation program, Dalbey Bottoms mitigation site. Final Project Implementation Report April 2010, 297 p.

USACE, 2012. Assessment of conceptual nonstructural alternative levee setbacks along the Missouri River (Lower L-575/Upper L-550 and Lower L-550). Final Report April 2012, 93 p.

USACE, 2013. 2011 Missouri River Levee Rehab Update, Omaha District, 2 p.

USFWS, 2000. U.S. Fish and Wildlife Service biological opinion on the operation of the Missouri River main stem reservoir system, operation and maintenance of the Missouri River bank stabilization and navigation project, and operation of the Kansas River reservoir system.

USFWS, 2003. Amendment to the 2000 biological opinion.

USFWS, 2009. Letter to USACE clarifying the definition of shallow water habitat.

Wetzel R.G., 2001. Limnology: lake and reservoir ecosystems, 3rd edition, Academic Press, San Diego, $1006 \mathrm{p}$.

Wiederholm T., 1980. Use of benthos in lake monitoring. J. Water Pollut. Control Fed., 52, 537-547.

Wiggins G.B., Mackay R.J. and Smith I.M., 1980. Evolutionary and ecological strategies of animals in annual temporary pools. Arch. fur Hydrobiol. Suppl., 58, 97-206. 